\title{
Agriculture's impact on microbial diversity and associated fluxes of carbon dioxide and methane
}

\author{
Uri Y Levine ${ }^{1,4}$, Tracy K Teal ${ }^{1}$, G Philip Robertson ${ }^{2,3}$ and Thomas M Schmidt ${ }^{1,2}$ \\ ${ }^{1}$ Department of Microbiology and Molecular Genetics, Michigan State University, East Lansing, MI, USA; \\ ${ }^{2}$ W.K. Kellogg Biological Station, Michigan State University, East Lansing, MI, USA and ${ }^{3}$ Department of \\ Crop and Soil Sciences, Michigan State University, East Lansing, MI, USA
}

\begin{abstract}
Agriculture has marked impacts on the production of carbon dioxide $\left(\mathrm{CO}_{2}\right)$ and consumption of methane $\left(\mathrm{CH}_{4}\right)$ by microbial communities in upland soils-Earth's largest biological sink for atmospheric $\mathrm{CH}_{4}$. To determine whether the diversity of microbes that catalyze the flux of these greenhouse gases is related to the magnitude and stability of these ecosystem-level processes, we conducted molecular surveys of $\mathrm{CH}_{4}$-oxidizing bacteria (methanotrophs) and total bacterial diversity across a range of land uses and measured the in situ flux of $\mathrm{CH}_{4}$ and $\mathrm{CO}_{2}$ at a site in the upper United States Midwest. Conversion of native lands to row-crop agriculture led to a sevenfold reduction in $\mathrm{CH}_{4}$ consumption and a proportionate decrease in methanotroph diversity. Sites with the greatest stability in $\mathrm{CH}_{4}$ consumption harbored the most methanotroph diversity. In fields abandoned from agriculture, the rate of $\mathrm{CH}_{4}$ consumption increased with time along with the diversity of methanotrophs. Conversely, estimates of total bacterial diversity in soil were not related to the rate or stability of $\mathrm{CO}_{2}$ emission. These combined results are consistent with the expectation that microbial diversity is a better predictor of the magnitude and stability of processes catalyzed by organisms with highly specialized metabolisms, like $\mathbf{C H}_{4}$ oxidation, as compared with processes driven by widely distributed metabolic processes, like $\mathrm{CO}_{2}$ production in heterotrophs. The data also suggest that managing lands to conserve or restore methanotroph diversity could mitigate the atmospheric concentrations of this potent greenhouse gas.
\end{abstract}

The ISME Journal (2011) 5, 1683-1691; doi:10.1038/ismej.2011.40; published online 14 April 2011

Subject Category: microbial ecology and functional diversity of natural habitats

Keywords: biodiversity; carbon dioxide; complementaritry hypothesis; ecosystem function; methane; agriculture

\section{Introduction}

Carbon dioxide $\left(\mathrm{CO}_{2}\right)$ and methane $\left(\mathrm{CH}_{4}\right)$ are currently responsible for about $80 \%$ of the radiative forcing from long-lived greenhouse gases in Earth's atmosphere (Forster et al., 2007). The atmospheric concentrations of both gases are higher than they have been over the past 650000 years and continue to rise (IPCC, 2007; Rigby et al., 2008). Land-use change, especially deforestation and row-crop agriculture (Schlesinger and Andrews, 2000; Smith et al., 2000), has an important role in determining the rate of these fluxes and also changes the structure of microbial communities in soil (Borneman and Triplett, 1997; Smith et al., 2000; Zhou et al., 2008).

Correspondence: TM Schmidt, Michigan State University, Department of Microbiology and Molecular Genetics, 6180 Biomedical \& Physical Sciences Building, East Lansing, MI 48824, USA.

E-mail: tschmidt@msu.edu

${ }^{4}$ Current address: Food Safety and Enteric Pathogens Research Unit, National Animal Disease Center, U.S. Department of Agriculture, Agricultural Research Service, Ames, IA 50010, USA.

Received 7 September 2010; revised 8 February 2011; accepted 8 February 2011; published online 14 April 2011
The linkage between altered trace gas emissions and microbial community structure in soil may be more than associative-contemporary models in ecology suggest a positive relationship between species diversity and the magnitude and stability of ecosystem processes catalyzed by those species (Tilman et al., 2001; Symstad et al., 2003; Fargione et al., 2007; Ives and Carpenter, 2007). Should this relationship also hold for the soil microbial communities responsible for trace gas production and consumption, opportunities may emerge for mitigating emissions. For microbes in soil, however, the relationship between species diversity and the magnitude and stability of trace gas fluxes has rarely been tested. Although evidence to date suggests that such a relationship is unlikely for decomposition and other soil processes broadly catalyzed by many microbes (Schimel, 1995; Groffman and Bohlen, 1999), diversity may matter substantially for processes catalyzed by microbial groups more specialized and depauperate (Cavigelli and Robertson, 2000).

We tested the hypothesis that the magnitude and stability of $\mathrm{CH}_{4}$ consumption in well-drained soils, a process catalyzed by relatively few bacteria, is 
positively correlated with the diversity of methanotrophs present. We also tested the corollary hypothesis that the magnitude and stability of $\mathrm{CO}_{2}$ production, a process carried out by all heterotrophic bacteria in soil, is not related to the diversity of bacteria present.

We measured in situ fluxes of $\mathrm{CO}_{2}$ and $\mathrm{CH}_{4}$ and assessed microbial diversity across five different land-use intensities at the Kellogg Biological Station Long-Term Ecological Research (KBS LTER) site in southwest Michigan. KBS LTER, with replicated plots of the same soil series (Crum and Collins, 1995) that differ in land use, represents an ideal system for determining how land use impacts microbial communities and the greenhouse gas fluxes they control. Past studies have typically investigated either gas flux or the microbial community at analogous sites, but rarely has the function mediated by the microbes and the microbial community been investigated simultaneously across a land-use gradient. Our intent was not to unravel the root causes of variation in either community structure or greenhouse gas flux, but to show an association that, if directional, could suggest insights into long-term management options for the microbial community and their gas fluxes. To our knowledge, this is the first study to correlate methanotroph and bacterial diversity to both the stability and magnitude of the associated in situ greenhouse gas fluxes across a successional land-use gradient, and to use the results to gain insights into management options for abatement of atmospheric greenhouse gas increases.

\section{Materials and methods}

Gas-flux measurements

In situ rates of $\mathrm{CH}_{4}$ consumption and $\mathrm{CO}_{2}$ production were measured using closed-cover flux chambers (Robertson et al., 2000) across a gradient of land uses at the KBS LTER site located in Hickory Corners, Michigan. Land-use treatments range from conventional row-crop agriculture (AG) (wheat-cornsoybean rotation, chisel plowed, conventional fertilizer and pesticide inputs) to intact, late-successional deciduous forest never converted to agriculture (DF), as well as three types of replicated successional communities: an early successional community abandoned in 1989 (ES), an unmanaged mid-successional community abandoned in the 1950s (SF), and a never-plowed never-planted community managed as an annually mowed grassland following forest clearing in 1960 (MG). All five treatments are replicated ( $n=3$ one hectare plots) on the same soil series with similar textures (Kalamazoo/Oshtemo, and are well-drained Typic hapludalfs (fine or coarse loamy, mixed)) (Crum and Collins, 1995)_but with land-use associated differences in net primary production, soil organic matter (Robertson et al., 2000), aggregation (Grandy and
Robertson, 2007), and derived properties, such as moisture content and diffusion. Additional site information is available at http://lter.kbs.msu.edu. Gas-flux measurements were typically made twice monthly between March and December: detailed protocols, field logs and data are available at http:// lter.kbs.msu.edu/datasets. Gas-flux data reported in this study are from 1993-2008 (KBS013-001), and soil moisture and soil temperature measures associated with the gas-flux data from 2003-2008 (KBS013_003 and KBS013_004) were downloaded on 2 March 2010. Data for treatments MG and SF are available from 1993-1997 and 2008. Averages incorporate all monthly measurements for the reported time period.

\section{Assessment of total bacterial diversity}

Five soil cores $(2.5 \times 10 \mathrm{~cm})$ were collected and pooled from each of two replicate plots in December 2008 representing the five land uses. Plant litter and roots were removed by sieving ( $4 \mathrm{~mm}$ sieve), which also served to homogenize the cores. The composited samples were flash frozen in liquid $\mathrm{N}_{2}$, transported to the laboratory on ice and stored at $-80^{\circ} \mathrm{C}$. In all, 5-g subsamples were ground in sterile sand and liquid $\mathrm{N}_{2}$ with a mortar and pestle. Microbes were lysed enzymatically and chemically, followed by isolation of the released DNA using acetyl trimethylammonium bromide-based method (Zhou et al., 1996) and further purification on cesium chloride gradients (Sambrook and Russell, 2001). Sequence tags for the V6 region of the $16 \mathrm{~S}$ rRNA-encoding gene were generated (Sogin et al., 2006) and sequenced using Life Science's 454 GS-FLX pyrosequencing chemistry (Huse et al., 2008) at the Woods Hole Marine Biological Laboratory Bay Paul Center. An average of 15800 sequence tags were generated for each sample. Membership in an operational taxonomic unit (OTU) was defined as sequences sharing 97\% nucleotide identity using the VAMPS MBL Bay Paul Center pipeline (Huse et al., 2008).

\section{Methanotroph census}

The diversity of methanotrophs across the KBS LTER landscapes was assessed via PCR amplification of the $\beta$-subunit of particulate methane monooxygenase $(p m o A)$. Template DNA for the amplification reactions was purified with the MoBio (Carlsbad, CA, USA) PowerSoil DNA Isolation Kit from $0.25 \mathrm{~g}$ subsamples from each of 75 soil cores collected in June 2006: 5 cores from each of 3 replicates of the 5 land-use treatments. $p m o A$ was amplified from $45 \mathrm{ng}$ of template DNA with primers A189 (5'-GGNG ACTGGGACTTCTGG-3') and A682 (5'-GAASGCNG AGAAGAASGC-3'; labeled with 6-carboxyfluorescein) (Holmes et al., 1995). The products of technical replicates of PCR reactions were pooled to minimize amplification bias, then purified and 
digested sequentially with three restriction endonucleases for terminal restriction fragment length polymorphisms analysis. See Supplementary Information for detailed protocols.

Clone libraries of $p m o A$ amplicons were created from a selection of soil samples and amplification conditions (Supplementary Table S1) to provide a molecular phylogeny of methanotrophs. Clone libraries were sampled until rarefaction curves were asymptotic (Supplementary Figure S5). Sequences from clone libraries were binned using DOTUR (Schloss and Handelsman, 2005), if they shared 94\% average nucleotide sequence similarity-a specieslevel designation for functional genes (Konstantinidis et al., 2006). Representative pmoA sequences were deposited in GenBank under accession numbers FJ529724-FJ529808, and GQ219582 and GQ219583.

\section{Statistical analysis}

The effect of land use on $\mathrm{CH}_{4}$ consumption and methanotroph richness was explored through $t$-tests, and a one-way multivariate analysis of variance (SAS Institute Inc., Cary, NC, USA). Linear regressions were used to relate mean greenhouse gas flux and species diversity, as well as the recovery of mean $\mathrm{CH}_{4}$ consumption and mean methanotroph diversity following cessation of agriculture. Multiple regression analysis was used to assess the relative contribution of temperature and soil moisture to gas flux. The Sørenson index was calculated for each pairwise comparison of methanotroph communities in KBS LTER treatments and plotted using two-dimensional non-metric multidimensional scaling (Hammer et al., 2001). A oneway analysis of similarities was used to assess the significance of differences between communities (Hammer et al., 2001).

\section{Results}

Greenhouse gas flux and abiotic regulators

Rates of $\mathrm{CH}_{4}$ consumption varied significantly with land use: the highest average annual rate of consumption was measured in the deciduous forest. Mid-successional fields, either abandoned from agriculture 50 years ago (SF) or never-tilled sites managed as grasslands (MG), consumed $\mathrm{CH}_{4}$ at a significantly decreased rate as compared with the forest (DF), but significantly higher than early successional plots (ES) or agricultural plots (AG) ( $t$-tests, $P<0.01$ ). The lowest rates of $\mathrm{CH}_{4}$ consumption were consistently recorded in plots currently managed for row-crop agriculture (Figure 1a). There was approximately a sevenfold difference between the average annual rate of $\mathrm{CH}_{4}$ consumption in the deciduous forest and the conventional agriculture plots (7.93 and $1.02 \mathrm{~g} \mathrm{CH}_{4}-\mathrm{Cha}^{-1}$ day $^{-1}$, respectively).
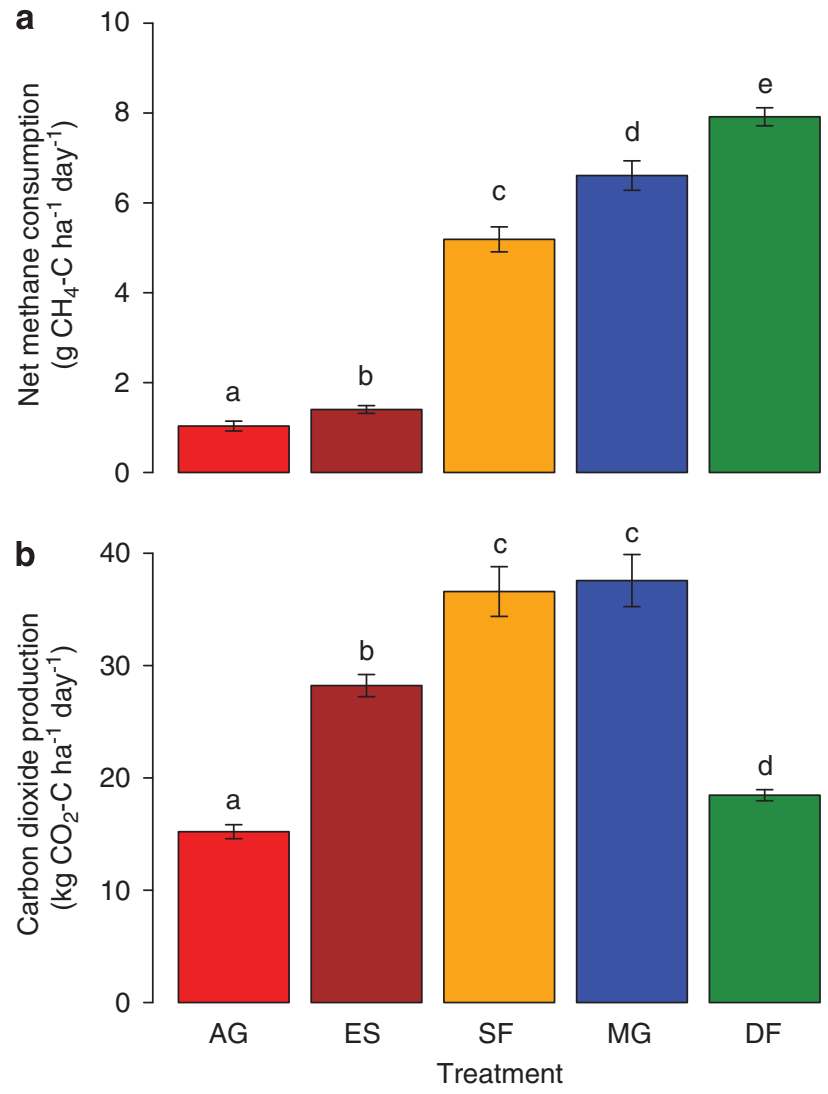

Figure 1 The effect of land use on $\mathrm{CH}_{4}$ consumption (a) and $\mathrm{CO}_{2}$ production (b) at the KBS LTER Site. Mean flux values are on the basis of all measurements available between 1993 and 2008. Land-use treatments are as follows: agricultural management of historically tilled lands (AG), early successional fields abandoned from agriculture in 1989 (ES), successional forests abandoned from agriculture in the 1950s (SF), managed grasslands on never tilled soil (MG), and deciduous forests (DF). Different letters represent significant differences $(P<0.05)$ between treatments. Error bars represent standard errors.

$\mathrm{CO}_{2}$ flux from soil also varied with land use. Soils in the early and mid-successional sites emitted $80 \%$ more $\mathrm{CO}_{2}$ than the agricultural site, whereas the rate in the deciduous forest was $18 \%$ higher than the agricultural site. The highest rates of $\mathrm{CO}_{2}$ emission and $\mathrm{CH}_{4}$ consumption were recorded during the summer months for all treatments (Supplementary Figure S1); seasonal flux patterns were similar for all land uses. Soil temperature and moisture, two master regulators of biological processes in soil, explained portions of both fluxes, but were 10 times more effective in explaining the efflux of $\mathrm{CO}_{2}$ $\left(r^{2}=0.12, P<0.001\right)$ than rates of $\mathrm{CH}_{4}$ consumption $\left(r^{2}=0.01, P=0.06\right)$.

\section{Methanotroph diversity and $\mathrm{CH}_{4}$ consumption}

To relate methanotroph diversity to annual averages of $\mathrm{CH}_{4}$ consumption across the gradient of land uses at the KBS LTER, a method employing terminal restriction fragment length polymorphisms was developed to capture all methanotrophs present, 
rather than methods that would assess metabolically active populations of methanotrophs at a particular time. The $p m o A$ gene was targeted for this assay because it encodes a subunit of particulate methane monooxygenase-the first enzyme in the pathway of $\mathrm{CH}_{4}$ oxidation and the defining enzyme of aerobic methanotrophs, except for Methylocella species (McDonald et al., 2008; Rahman et al., 2010). The terminal restriction fragment length polymorphism assay distinguished 11 OTUs that were confirmed as pmoA gene fragments both through sequence analysis and comigration of terminal restriction fragments with those from cloned controls. These 11 OTUs encompassed all of the major clades of methanotrophs defined by the pmoA gene sequences from clone libraries from KBS LTER (Supplementary Figure S2).

Methanotroph diversity, like the rates of $\mathrm{CH}_{4}$ consumption, also varied significantly with land use $(P<0.05$; analysis of variance) (Supplementary Table S2B). The fewest methanotroph OTUs and lowest rates of $\mathrm{CH}_{4}$ consumption were found in the agricultural plots, whereas the deciduous forest harbored the greatest number of methanotroph OTUs and the highest rates of $\mathrm{CH}_{4}$ consumption. Modeling treatment effects on rates of $\mathrm{CH}_{4}$ consumption while excluding methanotroph diversity as a covariate yielded reduced experimental error and indicated that methanotroph richness influences the rate of $\mathrm{CH}_{4}$ consumption (Supplementary Table S2C).

There was a strong positive correlation between average annual rates of $\mathrm{CH}_{4}$ consumption and the number of $p m o A$ OTUs across the KBS LTER landscapes $\left(r^{2}=0.52, P<0.004\right)$ (Figure 2a). Regression of annual rates of $\mathrm{CH}_{4}$ consumption from 19932008 versus $p m o A$ diversity yields a nearly identical relationship $\left(r^{2}=0.55, P=0.002\right)$, as does summer rates of $\mathrm{CH}_{4}$ consumption $\left(r^{2}=0.52, P=0.003\right)$.

To further explore methanotroph diversity and search for new pmoA genes, 12 pmoA clone libraries were created from DF and AG samples with additional amplification conditions (Supplementary Table S1, SI text). All libraries were sampled until rarefaction curves were asymptotic (Supplementary Figure S5), in an effort to capture the full sequence diversity in each library. Although altered amplification conditions captured some additional $\mathrm{pmo} A$ genes, diversity was always greater in the forested plots as compared with the agricultural treatment (Supplementary Figure S3). Clone libraries revealed a new clade of methanotrophs, KBS1 (Supplementary Figures S2, S3), in addition to those previously identified in soils (Horz et al., 2005; Knief et al., 2005; Lau et al., 2007). Using a species definition of $94 \%$ identity in functional genes (Konstantinidis et al., 2006), 24 methanotrophic species were identified in cumulative libraries from the forested plots, but only 7 from the agricultural plots. As has been described previously, some subunits from ammonia monooxygenase genes (amoA) also
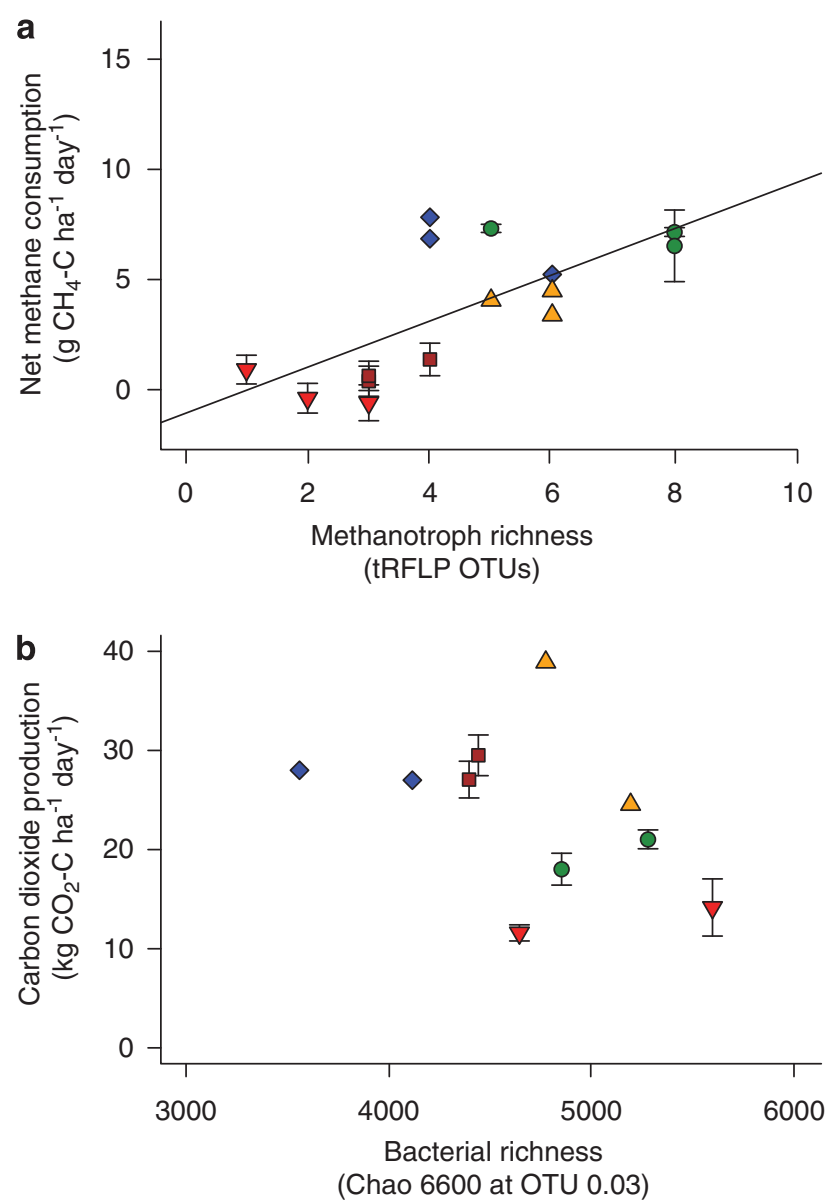

Figure 2 Relationship between average annual $\mathrm{CH}_{4}$ consumption and methanotroph richness $\left(a: r^{2}=0.52, P<0.004\right)$, and between average annual $\mathrm{CO}_{2}$ production and bacterial richness (b: $r^{2}=0.17, P=0.22$ ) across land-use treatments at the KBS LTER. Gas flux and diversity data were collected between 2006 and 2008. Methanotroph richness is represented by OTUs that are on the basis of peaks in the terminal restriction fragment length polymorphism analysis that have been confirmed as originating from $p m o A$ genes. Detailed descriptions of symbols can be found in the legend to Figure 1: $\boldsymbol{\nabla}=\mathrm{AG}, \boldsymbol{\nabla}=\mathrm{ES}, \boldsymbol{\Delta}=\mathrm{SF}, \boldsymbol{\diamond}=\mathrm{MG}$, $\boldsymbol{0}=\mathrm{DF}$. Error bars represent standard errors.

amplified with the pmoA primers (Holmes et al., 1995). The amo $A$ clones were recognized by the presence of diagnostic amino acids (Horz et al., 2005; Stoecker et al., 2006) and their clustering in phylogenetic trees (Supplementary Figure S3). They were excluded from methanotroph diversity estimates.

Bacterial diversity and $\mathrm{CO}_{2}$ flux

We estimated bacterial diversity through analysis of 454 pyrosequencing of the V6 region of the $16 \mathrm{~S}$ rRNA encoding gene (Sogin et al., 2006) and clustering reads at $97 \%$ identity (Huse et al., 2007). An average of 15800 sequence tags was analyzed for each of the replicated samples. Rarefaction curves (Supplementary Figure S6) suggest that we did not capture the full sequence diversity, and so we used the Chao 1 estimator of 

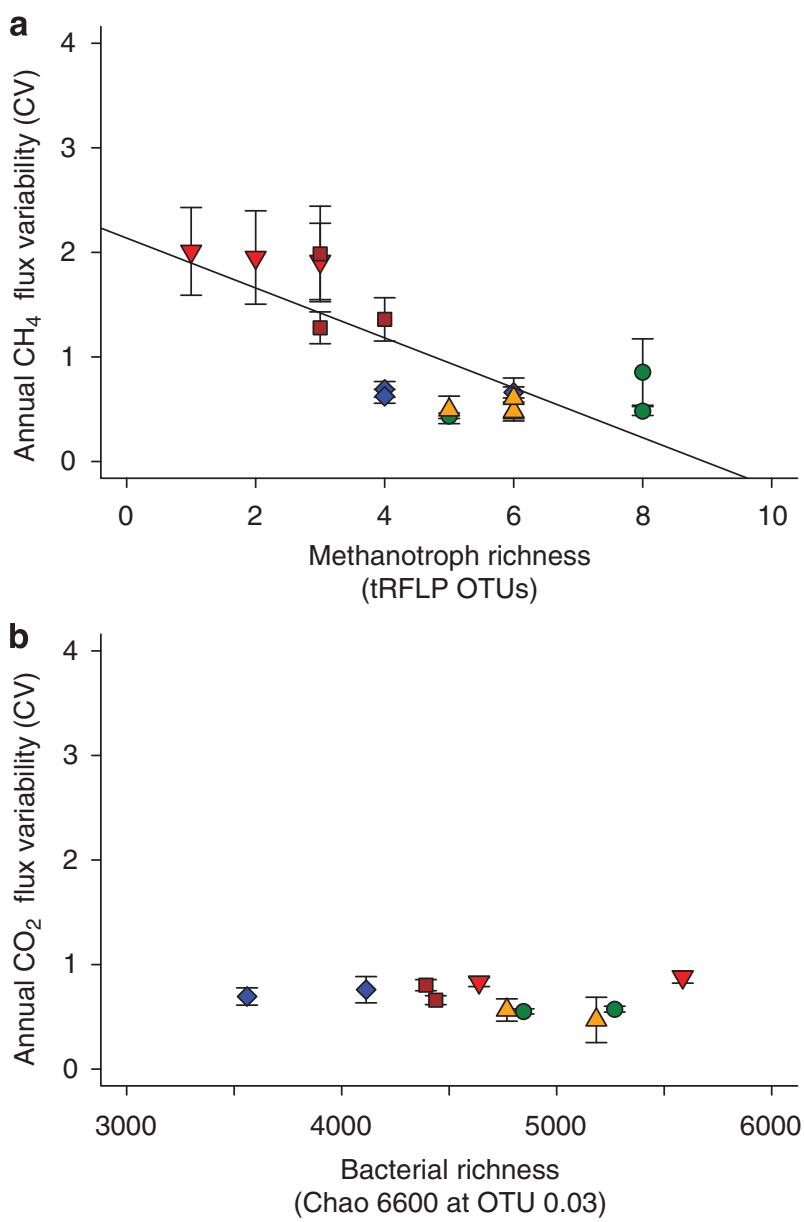

Figure 3 Variability in the flux of $\mathrm{CH}_{4}$ in relation to the diversity of methanotrophs $\left(\mathbf{a} ; r^{2}=0.59, P<0.001\right)$, and variability in the flux of $\mathrm{CO}_{2}$ in relationship to total bacterial diversity $\left(\mathbf{b} ; r^{2}=0.02\right.$, $P=0.66$ ). Means and standard errors of the coefficients of variance for the annual flux are on the basis of measurements collected between 2006-2008. Detailed descriptions of symbols can be found in the legend to Figure 1: $\boldsymbol{\nabla}=\mathrm{AG}, \boldsymbol{\square}=\mathrm{ES}, \boldsymbol{\Delta}=\mathrm{SF}$, $\bullet=\mathrm{MG}, \boldsymbol{\bullet}=\mathrm{DF}$. Error bars represent standard errors.

richness (Chao, 1984) to compare diversity. To control for unequal sequencing depths, we estimated richness in each sample at 6600 sequences, the Chao 1 estimate from our lowest sequenced sample. There was no obvious relationship between $\mathrm{CO}_{2}$ production and estimated bacterial diversity $(P=0.522$ for linear regression, Figure $2 \mathrm{~b})$.

Influence of diversity on stability

To assess variability in the flux of $\mathrm{CO}_{2}$ and $\mathrm{CH}_{4}$ across treatments, we compared the coefficient of variance in the annual fluxes for each land management practice in each year between 2006 and 2008, the years for which molecular data was collected. The variance in $\mathrm{CH}_{4}$ was negatively correlated with methanotroph diversity $(P<0.001)$ : sites with the highest richness had the lowest variance (Figure 3a). Conversely, variation of $\mathrm{CO}_{2}$ flux was not correlated with overall bacterial diversity (Figure $3 b$ ).

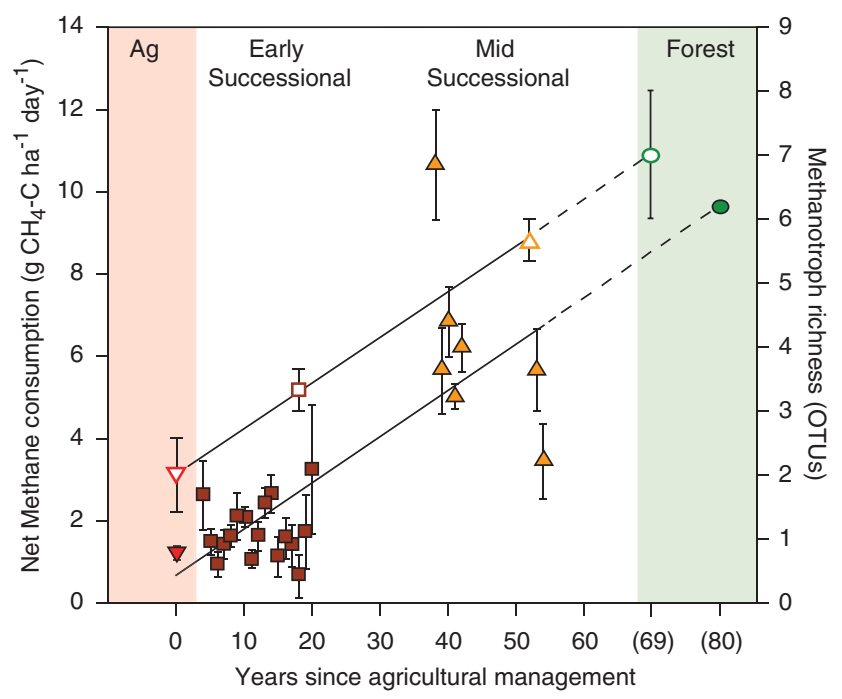

Figure 4 The recovery of methanotroph diversity and $\mathrm{CH}_{4}$ consumption at KBS LTER following row-crop agriculture. Increase in methanotroph diversity (open symbols) and $\mathrm{CH}_{4}$ consumption (closed symbols) as a function of time since cessation of agriculture. Measurements of the deciduous forest (DF) are positioned on the basis of projections from linear regression used to fit methanotroph diversity $(\mathrm{y}=0.07 \mathrm{x}+2.05$; $\left.r^{2}=0.99, P=0.020\right)$ or $\mathrm{CH}_{4}$ consumption $(\mathrm{y}=0.11 \mathrm{x}+0.67$; $r^{2}=0.56, P<0.001$ ). All measurements (diversity and consumption) are annual averages with error bars representing standard errors. Detailed descriptions of symbols can be found in the legend to Figure 1: $\boldsymbol{\nabla}=\mathrm{AG}, \boldsymbol{\nabla}=\mathrm{ES}, \boldsymbol{\Delta}=\mathrm{SF}, \boldsymbol{\bullet}=\mathrm{MG}, \boldsymbol{\bullet}=\mathrm{DF}$.

\section{Recovery from agriculture}

Given the relationship between methanotroph diversity and $\mathrm{CH}_{4}$ flux, changes in the membership of the methanotroph community were assessed following the release of lands from row-crop agriculture. The community of methanotrophs differed following the abandonment of agricultural practices $(P<0.005$, analysis of similarity), and soils began to recover in terms of $\mathrm{CH}_{4}$ consumption and methanotroph diversity (Figure 4). The methanotroph species present in the mid-successional plots began to overlap with those in fields that have not been used for agriculture (MG and DF) (Supplementary Figure S4).

There was a linear trajectory for the recovery of both $\mathrm{CH}_{4}$ consumption $\left(r^{2}=0.56, P<0.001\right)$ and methanotroph richness $\left(r^{2}=0.99, P=0.020\right)$ over time with the slopes of these lines nearly parallel. Extrapolation of the linear relationships suggests that approximately 80 years would be required for full restoration of $\mathrm{CH}_{4}$ consumption and methanotroph diversity to the levels of the current deciduous forest (Figure 4).

\section{Discussion}

Species richness is an integral component of community ecology, with the richness of plant species linked to productivity (Tilman et al., 2001) and greater temporal stability in plant production 
1688

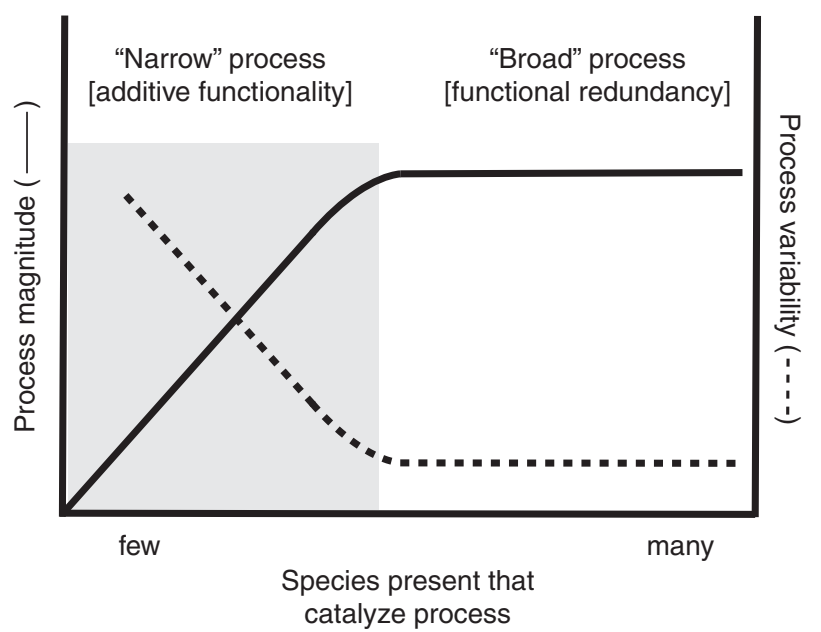

Figure 5 Conceptual model of the relationships between the number of species present in an environment that catalyze a particular ecosystem process (richness) and the magnitude and variability (1 per stability) of that process. Processes catalyzed by microbes with specialized metabolisms that are mediated by a few species are proposed to occur in the shaded area.

(Tilman et al., 2006) across many landscapes (Wacker et al., 2009). Although the mechanisms underlying these relationships for macroorganisms are vigorously debated and investigated, microbiologists are just beginning to ask whether functionality, stability and diversity are correlated in microbial communities (Konopka, 2009).

We investigated the relationship between microbial diversity and two ecosystem-level processes that are catalyzed by soil microbes-the consumption of $\mathrm{CH}_{4}$ and the production of $\mathrm{CO}_{2}$. On the basis of ecological models and considerations of biodiversity and microbial metabolism in soil (Schimel, 1995; Groffman and Bohlen, 1999; Zak et al., 2003), we hypothesized that the relationship between microbial diversity and the magnitude and stability of gas fluxes would depend on the total number of species that are present to catalyze each process (Figure 5). If this model is true, the rate and stability of $\mathrm{CH}_{4}$ consumption, which is a specialized metabolic process limited to relatively few species, would be positively correlated with methantroph richness, whereas $\mathrm{CO}_{2}$ production, the result of general metabolic pathways shared by thousands of different heterotrophs in soil, would not be related to bacterial diversity.

As postulated, there was a positive relationship between rates of $\mathrm{CH}_{4}$ consumption and the diversity of methanotrophs across a range of land uses at the KBS LTER (Figure 2a). The observed changes in methanotroph richness are consistent with other studies where methanotroph diversity increased in reforested farmland (Knief et al., 2005; Dorr et al., 2010) and reclaimed pasture lands (Zhou et al., 2008), and where methanotroph richness was linked to $\mathrm{CH}_{4}$ consumption in other sites (Lin et al., 2005; Singh et al., 2007; Degelmann et al., 2010). Our study establishes a definitive correlation between methanotroph richness and $\mathrm{CH}_{4}$ consumption across a successional gradient of landscapes from row-crop agriculture to deciduous forest.

Changes in methanotroph diversity and $\mathrm{CH}_{4}$ consumption along this gradient highlight the strong and long-lasting impact of agricultural management. On the basis of recovery of $\mathrm{CH}_{4}$ consumption following abandonment from agriculture, we project that it will require approximately 80 years for methanotroph diversity and $\mathrm{CH}_{4}$ consumption to return to that of a native deciduous forest (Figure 4b). This slow recovery is consistent with worldwide observations that suggest a recovery period of 100 years for $\mathrm{CH}_{4}$ consumption (Smith et al., 2000).

In contrast, we found no observable relationship between bacterial diversity in soil and large differences in the production of $\mathrm{CO}_{2}$ (Figure 2b). Given the extensive microbial diversity in soils and the ubiquitous distribution of $\mathrm{CO}_{2}$-yielding metabolic pathways in heterotrophs, it is perhaps not surprising that there was no discernible relationship between diversity and soil respiration. The lack of a general relationship between bacterial diversity and soil respiration has been documented for other soil types as well (Balser and Firestone, 2005; Wertz et al., 2006). Rather than being related to bacterial diversity, we found that $\mathrm{CO}_{2}$ production from soil was more strongly predicted by soil moisture and temperature-two well-known regulators of soil metabolism (Cook and Orchard, 2008). Respiration of fungi, soil arthropods and plant roots also respond to these master regulators, making it difficult to disentangle the relative contribution from members of this complex community of organisms, but at the KBS LTER, bacterial diversity is not one of the driving factors.

Variability in both $\mathrm{CH}_{4}$ consumption and $\mathrm{CO}_{2}$ production are also consistent with the postulated model (Figure 5). Variation in $\mathrm{CH}_{4}$ consumption was highest in agricultural plots that harbored the lowest diversity, whereas plots with the highest diversity were the most stable. We suggest that increased stability arises from the presence of complementary niches of methanotrophs. As environments vary temporally or spatially across a landscape, the presence of a more diverse assortment of methanotrophs that are able to oxidize $\mathrm{CH}_{4}$ under a broader set of environmental conditions provides for more consistent $\mathrm{CH}_{4}$ consumption. We also recognize that some variability may be contributed by technical limitations associated with the measurement of low rates of $\mathrm{CH}_{4}$ consumption. Variability in $\mathrm{CO}_{2}$ flux was smaller than for $\mathrm{CH}_{4}$ flux, and there was no obvious relationship to bacterial diversity. As predicted by our model, once there is sufficient redundancy in a metabolic process, the gain or loss of species is not expected to influence the overall rate or stability of the process catalyzed by that metabolic group of microbes. It is noteworthy that both aspects of the model are captured in the same 
sample: a broadly distributed process not linked to ecosystem function and a specialized, narrowly distributed process linked to the magnitude and stability of a process. This suggests that efforts to mediate the impact of agricultural practices on greenhouse gas flux is best focused on organisms and factors contributing to narrowly distributed processes.

Two hypotheses have been advanced to explain the underlying basis of the relationship between ecosystem-level processes and diversity: the magnitude of a process can be the result of the combined activities of species present (complementarity hypothesis), or the magnitude can be the result of the presence of one or a few particularly productive species more likely to be present when diversity is high (sampling hypothesis) (Loreau and Hector, 2001; Fargione et al., 2007). Distinguishing between these competing hypotheses would determine whether all methanotrophs or only select species need to be conserved or restored in order to stimulate $\mathrm{CH}_{4}$ consumption where it has been attenuated by change in land use. If cumulative diversity were of primary importance, as suggested in the complementarity hypothesis, strategies that stimulate the growth of all methanotrophs would be most effective. If, on the other hand, certain high-activity species are the primary drivers of $\mathrm{CH}_{4}$ consumption, as suggested by the selection hypothesis, then strategies should be directed towards the establishment of those specific methanotrophs. The concurrent recovery of $\mathrm{CH}_{4}$ oxidation and methanotroph diversity following the abandonment from row-crop agriculture (Figure 4) and the successive accumulation of methanotroph species in addition to those present in the agricultural site (Supplementary Figures S3, S4, Supplementary Table S1) is consistent with the complementarity of methanotrophs leading to increased functionality. Continued monitoring of the recovery of both methanotrophs and $\mathrm{CH}_{4}$ consumption, coupled with functional assays to determine which methanotroph populations are most active throughout the year will provide a rigorous test of these alternative hypotheses.

The slow recovery of $\mathrm{CH}_{4}$ consumption following the abandonment of agricultural management practices suggests that many dimensions of methanotroph niches are disrupted by row-crop agriculture. Recovery of the diversity of methanotroph communities has been observed in sites where plant diversity was increased (Knief et al., 2005; King and Nanba, 2008; Zhou et al., 2008; Degelmann et al., 2010; Dorr et al., 2010), perhaps due to the differential production of monoterpenes (Maurer et al., 2008; Degelmann et al., 2010), suggesting a role for plant diversity in shaping methanotroph communities. Additionally, nitrogen fertilization is known to change the structure of methanotroph communities (Lau et al., 2007; Maxfield et al., 2008), most likely through competitive inhibition of methane monooxygenase by ammonia (Gulledge and Schimel, 1998), although it can stimulate $\mathrm{CH}_{4}$ consumption under conditions where fixed nitrogen is limiting methanotroph metabolism (Bodelier and Laanbroek, 2004). At KBS LTER, ammonia has been shown to cause acute short-term reductions in $\mathrm{CH}_{4}$ consumption rates in DF and SF soils (Suwanwaree and Robertson, 2005). Within the land-use gradient at KBS LTER, differences in gas diffusivity (von Fischer et al., 2009), the disruption of soil aggregates by tillage (Grandy and Robertson, 2007), nitrogen fertilization, as well as documented drivers of microbial diversity (including $\mathrm{pH}$ and salinity (Fierer and Jackson, 2006)), are additional factors that might be influencing methanotroph diversity and rates of $\mathrm{CH}_{4}$ consumption. Identifying parameters that influence methanotroph diversity, including the influence of soil type and climate across sites, will be of vital importance if we are to manage lands to conserve or restore methanotroph diversity and enhance the capacity of soil to serve as a stable sink for atmospheric $\mathrm{CH}_{4}$.

\section{Conclusions}

One of the most important drivers of species loss in terrestrial ecosystems worldwide is simplification of ecosystem structure that results from intensified land use (Sala et al., 2000). We document a decrease in both methanotroph diversity and $\mathrm{CH}_{4}$ consumption in soils managed for row-crop agriculture compared with native deciduous forests and nevertilled soils managed as grasslands. There was not a similar relationship between soil respiration and bacterial richness, consistent with the prediction that microbial diversity is more likely to be important in the case of specialized metabolic processes rather than broadly distributed types of metabolism and that specialized processes are better targets for microbial mediation. The concomitant recovery of methanotroph diversity and $\mathrm{CH}_{4}$ consumption suggests that all methanotroph species contribute to $\mathrm{CH}_{4}$ consumption as suggested by the complementarity hypothesis. Identifying parameters that impact methanotroph diversity will inform decisions about land management that have the potential to influence the flux of this potent greenhouse gas.

\section{Acknowledgements}

We thank members of the Schmidt laboratory for many useful discussions and comments on this research and the Marine Biological Laboratory Bay Paul Center for sequencing. This research was supported by the U.S. National Science Foundation (MCB-0731913 and the LTER program), and the DOE Great Lakes Bioenergy Research Center (DOE BER Office of Science DE-FC02-07ER64494 and DOE OBP Office of Energy Efficiency and Renewable Energy DE-AC05-76RL01830). UYL was supported in part by an EPA Star Fellowship. TKT is supported by an NSF postdoctoral fellowship in Biological Informatics. 


\section{References}

Balser TC, Firestone MK. (2005). Linking microbial community composition and soil processes in a California annual grassland and mixed-conifer forest. Biogeochemistry 73: 395-415.

Bodelier PL, Laanbroek HJ. (2004). Nitrogen as a regulatory factor of methane oxidation in soils and sediments. FEMS Microbiol Ecol 47: 265-277.

Borneman J, Triplett EW. (1997). Molecular microbial diversity in soils from eastern Amazonia: evidence for unusual microorganisms and microbial population shifts associated with deforestation. Appl Environ Microbiol 63: 2647-2653.

Cavigelli MA, Robertson GP. (2000). The functional significance of denitrifier community composition in a terrestrial ecosystem. Ecology 81: 1402-1414.

Chao A. (1984). Non-parametric estimation of the number of classes in a population. Scand J Stat 11: 265-270.

Cook FJ, Orchard VA. (2008). Relationships between soil respiration and soil moisture. Soil Biol Biochem 40: 1013-1018.

Crum JR, Collins HP. (1995). KBS Soils (online). W. K. Kellogg Biological Station Long-Term Ecological Research Project, Michigan State University, Hickory Corners, MI. Available at http://lter.kbs.msu.edu/about/ site_description/soils.php(verified 2 February 2011).

Degelmann DM, Borken W, Drake HL, Kolb S. (2010). Atmospheric methane-oxidizing communities differ in European Beech and Norway Spruce soils. Appl Environ Microbiol 76: 3228-3235.

Dorr N, Glaser B, Kolb S. (2010). Methanotrophic communities in Brazilian ferralsols from naturally forested, afforested, and agricultural sites. Appl Environ Microbiol 76: 1307-1310.

Fargione J, Tilman D, Dybzinski R, Lambers JHR, Clark C, Harpole WS et al. (2007). From selection to complementarity: shifts in the causes of biodiversity-productivity relationships in a long-term biodiversity experiment. Proc R Soc B Biol Sci 274: 871-876.

Fierer N, Jackson RB. (2006). The diversity and biogeography of soil bacterial communities. Proc Natl Acad Sci USA 103: 626-631.

Forster P, Ramaswamy V, Artaxo P, Berntsen T, Betts R, Fahey DW et al. (2007). Changes in atmospheric constituents and in radiative forcing. In: Solomon $S$, Qin D, Manning M, Chen Z, Marquis M, Averyt K et al (eds). Climate Change 2007: The Physical Science Basis Contribution of Working Group I to the Fourth Assessment Report of the Intergovernmental Panel on Climate Change. Cambridge University Press: Cambridge, pp 129-234.

Grandy AS, Robertson GP. (2007). Land-Use Intensity Effects on Soil Organic Carbon Accumulation Rates and Mechanisms, vol. 10. Springer: New York, 16pp.

Groffman PM, Bohlen PJ. (1999). Soil and sediment biodiversity-cross-system comparisons and largescale effects. Bioscience 49: 139-148.

Gulledge J, Schimel JP. (1998). Low-concentration kinetics of atmospheric $\mathrm{CH} 4$ oxidation in soil and mechanism of NH4+ inhibition. Appl Environ Microbiol 64: 4291-4298.

Hammer Ø, Harper DAT, Ryan PD. (2001). PAST: paleontological statistics software package for education and data analysis. Palaeontol Electron 4: 1-9.

Holmes AJ, Costello A, Lidstrom ME, Murrell JC. (1995). Evidence that participate methane monooxygenase and ammonia monooxygenase may be evolutionarily related. FEMS Microbiol Lett 132: 203-208.

Horz H-P, Rich V, Avrahami S, Bohannan BJM. (2005). Methane-oxidizing bacteria in a California upland grassland soil: diversity and response to simulated global change. Appl Environ Microbiol 71: 2642-2652.

Huse S, Huber J, Morrison H, Sogin M, Welch D. (2007). Accuracy and quality of massively parallel DNA pyrosequencing. Genome biol 8: R143.

Huse SM, Dethlefsen L, Huber JA, Mark Welch D, Relman DA, Sogin ML. (2008). Exploring microbial diversity and taxonomy using SSU rRNA hypervariable tag sequencing. PLoS Genet 4: e1000255.

IPCC (2007). In: Team CW, Pachauri RK, Reisinger A (eds). Climate Change 2007: Synthesis Report. Contribution of Working Groups I, II and III to the Fourth Assessment Report of the Intergovernmental Panel on Climate Change. IPCC: Geneva, Switzerland.

Ives AR, Carpenter SR. (2007). Stability and diversity of ecosystems. Science 317: 58-62.

King GM, Nanba K. (2008). Distribution of atmospheric methane oxidation and methanotrophic communities on Hawaiian volcanic deposits and soils. Microbes Environ 23: 326-330.

Knief C, Vanitchung S, Harvey NW, Conrad R, Dunfield PF, Chidthaisong A. (2005). Diversity of methanotrophic bacteria in tropical upland soils under different land uses. Appl Environ Microbiol 71: 3826-3831.

Konopka A. (2009). What is microbial community ecology? ISME J 3: 1223-1230.

Konstantinidis KT, Ramette A, Tiedje JM. (2006). The bacterial species definition in the genomic era. Philos Trans $R$ Soc Lond B Biol Sci 361: 1929-1940.

Lau E, Ahmad A, Steudler PA, Cavanaugh CM. (2007). Molecular characterization of methanotrophic communities in forest soils. FEMS Microbiol Ecol 60: 490-500.

Lin JL, Joye SB, Scholten JCM, Schafer H, McDonald IR, Murrell JC. (2005). Analysis of methane monooxygenase genes in mono lake suggests that increased methane oxidation activity may correlate with a change in methanotroph community structure. Appl Environ Microbiol 71: 6458-6462.

Loreau M, Hector A. (2001). Partitioning selection and complementarity in biodiversity experiments. Nature 412: $72-76$.

Maurer D, Kolb S, Haumaier L, Borken W. (2008). Inhibition of atmospheric methane oxidation by monoterpenes in Norway spruce and European beech soils. Soil Biol Biochem 40: 3014-3020.

Maxfield PJ, Hornibrook ERC, Evershed RP. (2008). Acute impact of agriculture on high-affinity methanotrophic bacterial populations. Environ Microbiol 10: 1917-1924.

McDonald IR, Bodrossy L, Chen Y, Murrell JC. (2008). Molecular ecology techniques for the study of aerobic methanotrophs. Appl Environ Microbiol 74: 1305-1315.

Rahman MT, Crombie A, Chen Y, Stralis-Pavese N, Bodrossy L, Meir P et al. (2010). Environmental distribution and abundance of the facultative methanotroph methylocella. ISME J, e-pub ahead of print; doi:10.1038/ismej.2010.190.

Rigby M, Prinn RG, Fraser PJ, Simmonds PG, Langenfelds RL, Huang J et al. (2008). Renewed growth of atmospheric methane. Geophys Res Lett 35: doi:10.1029/ $2008 G L 036037$. 
Robertson GP, Paul EA, Harwood RR. (2000). Greenhouse gases in intensive agriculture: contributions of individual gases to the radiative forcing of the atmosphere. Science 289: 1922-1925.

Sala OE, Chapin FS, Armesto JJ, Berlow E, Bloomfield J, Dirzo R et al. (2000). Biodiversity-global biodiversity scenarios for the year 2100. Science 287: 1770-1774.

Sambrook J, Russell DW. (2001). Molecular Cloning: A Laboratory Manual, vol. 1. Cold Spring Harbor Laboratory Press: Cold Spring Harbor, NY.

Schimel JP. (1995). Ecosytem consequences of microbial diversity and community structure. In: Chapin III FS and Korner C (eds). Arctic and Alpine Biodiversity: Patterns, Causes and Ecosystem Consequences. Springer-Verlag: Berlin, pp 239-269.

Schlesinger WH, Andrews JA. (2000). Soil respiration and the global carbon cycle. Biogeochemistry 48: 7-20.

Schloss PD, Handelsman J. (2005). Introducing DOTUR, a computer program for defining operational taxonomic units and estimating species richness. Appl Environ Microbiol 71: 1501-1506.

Singh BK, Tate KR, Kolipaka G, Hedley CB, Macdonald CA, Millard P et al. (2007). Effect of afforestation and reforestation of pastures on the activity and population dynamics of methanotrophic bacteria. Appl Environ Microbiol 73: 5153-5161.

Smith KA, Dobbie KE, Ball BC, Bakken LR, Sitaula BK, Hansen S et al. (2000). Oxidation of atmospheric methane in Northern European soils, comparison with other ecosystems, and uncertainties in the global terrestrial sink. Global Change Biol 6: 791-803.

Sogin ML, Morrison HG, Huber JA, Welch DM, Huse SM, Neal PR et al. (2006). Microbial diversity in the deep sea and the underexplored 'rare biosphere'. Proc Natl Acad Sci USA 103: 12115-12120.

Stoecker K, Bendinger B, Schoning B, Nielsen PH, Nielsen JL, Baranyi C et al. (2006). Cohn's Crenothrix is a filamentous methane oxidizer with an unusual methane monooxygenase. Proc Natl Acad Sci USA 103: 2363-2367.
Suwanwaree P, Robertson GP. (2005). Methane oxidation in forest, successional, and no-till agricultural ecosystems: effects of nitrogen and soil disturbance. Soil Sci Am J 69: 1722-1779.

Symstad AJ, Chapin FS, Wall DH, Gross KL, Huenneke LF, Mittelbach GG et al. (2003). Long-term and large-scale perspectives on the relationship between biodiversity and ecosystem functioning. Bioscience 53: 89-98.

Tilman D, Reich PB, Knops J, Wedin D, Mielke T, Lehman C. (2001). Diversity and productivity in a long-term grassland experiment. Science 294: 843-845.

Tilman D, Reich PB, Knops JMH. (2006). Biodiversity and ecosystem stability in a decade-long grassland experiment. Nature 441: 629-632.

von Fischer JC, Butters G, Duchateau PC, Thelwell RJ, Siller R. (2009). In situ measures of methanotroph activity in upland soils: a reaction-diffusion model and field observation of water stress. J Geophys Res 114: G01015.

Wacker L, Baudois O, Eichenberger-Glinz S, Schmid B. (2009). Diversity effects in early- and mid-successional species pools along a nitrogen gradient. Ecology 90: $637-648$.

Wertz S, Degrange V, Prosser JI, Poly F, Commeaux C, Freitag T et al. (2006). Maintenance of soil functioning following erosion of microbial diversity. Environ Microbiol 8: 2162-2169.

Zak DR, Holmes WE, White DC, Peacock AD, Tilman D. (2003). Plant diversity, soil microbial communities, and ecosystem function: are there any links? Ecology 84: 2042-2050.

Zhou J, Bruns M, Tiedje J. (1996). DNA recovery from soils of diverse composition. Appl Environ Microbiol 62: 316-322.

Zhou X-Q, Wang Y-F, Huang X-Z, Hao Y-B, Tian J-Q, Wang J-Z. (2008). Effects of grazing by sheep on the structure of methane-oxidizing bacterial community of steppe soil. Soil Biol Biochem 40: 258-261.

Supplementary Information accompanies the paper on The ISME Journal website (http://www.nature.com/ismej) 